\title{
Promoting the export of environmental technologies: An analysis of governmental initiatives from eight countries
}

\author{
Wisdom Kanda, Olof Hjelm and Santiago Mejiá-Dugand
}

\section{Linköping University Post Print}

\section{Tweet}

N.B.: When citing this work, cite the original article.

Original Publication:

Wisdom Kanda, Olof Hjelm and Santiago Mejiá-Dugand, Promoting the export of environmental technologies: An analysis of governmental initiatives from eight countries, 2015, Environmental Development.

http://dx.doi.org/10.1016/j.envdev.2015.09.009

Copyright: Elsevier

http://www.elsevier.com/

Postprint available at: Linköping University Electronic Press

http://urn.kb.se/resolve?urn=urn:nbn:se:liu:diva-122234 


\title{
Promoting the export of environmental technologies: An analysis of governmental initiatives from eight countries
}

\author{
Wisdom Kanda*, Olof Hjelm, Santiago Mejía-Dugand \\ Environmental Technology and Management, Department of Management and Engineering, \\ Linköping University, SE-581 83 Linköping, Sweden.
}

*Corresponding author: E-mail address: wisdom.kanda@liu.se Tel.: +46 (0)13281696

\begin{abstract}
Export represents a means for the diffusion of environmental technologies with potential socio-economic and environmental benefits. However, environmental technology providers experience export barriers which stifle export and thus several governments continue to formulate export promotion initiatives towards this sector. Although export promotion is identified as essential in the environmental technology policy literature, it is yet to receive attention as to which initiatives are available in different countries including their potential relevance for environmental sustainability. Such knowledge is fundamental for policy learning and transfer including identification of good practices.

To address this knowledge gap, we use market failure and comparative public policy theories to analyse export promotion initiatives from export promotion and export credit agencies across eight countries in Asia, Europe, and North America. Three major conclusions emerge: (1) governmental initiatives to promote environmental technology export can be categorised under financial aid, information provision, education and training, and trade mobility programs; (2) policy choices regarding promotion initiatives are mediated by the institutional context and interests of policy actors (3) relevant aspects of such initiatives for environmental sustainability include the incorporation of particular environmental technology characteristics in initiative formulation, and the prioritisation between different technology and markets types for implementation.
\end{abstract}

Keywords: environmental technology; export promotion; market failure; comparative public policy; technology policy 


\section{Introduction}

How to tackle environmental problems such as climate change, natural resource depletion, and biodiversity loss remains a pressing question among political, industrial and academic actors. The attention given to these environmental problems can be partly attributed to their global nature, persistence through time and their implications on socio-economic activities (Finco and Nijkamp, 2001). On the other hand, these environmental problems present opportunities for systemic changes towards sustainability. Such sustainability transition will require multi-dimensional, long-term, and deep-structural changes in existing technologies, infrastructure, lifestyle, and institutions (Rennings, 2000). Albeit not sufficient, the development, market introduction, and international diffusion of innovative and environmentally relevant technologies are an important requirement for a global sustainability transition (del Rio González, 2009; Rennings, 2014).

Despite potential socio-economic and environmental benefits from the development, market introduction, and implementation of environmental technologies ${ }^{1}$, government intervention through policy has been necessary in instances where market incentives have not produced the desired levels of investment in the development and diffusion of environmental technologies (Jaffe et al., 2005; Schubert and Sedlacek, 2005). In addition, continued efforts by international organizations such as the OECD and UNEP to stimulate industrial activities towards sustainability point to the need for improvements in the diffusion levels of environmental technologies (Carrillo-Hermosilla et al., 2009). Against this background, several governments continue to formulate initiatives to support firm-level technology provider's development, market introduction, and international diffusion of environmental technologies (Kanda et al., 2013; Suzuki, 2014).

The international diffusion of environmental technologies can be channelled through foreign direct investment, technology transfer, the expansion of lead markets, and export. Firms and governments are interested in export because it presents the strategic flexibility to tackle global environmental challenges as business opportunities while potentially contributing to environmental improvements. However, firms exporting environmental technologies need to overcome certain export barriers to ensure that these technologies will provide the desired socio-economic benefits. Thus governments in different countries formulate export promotion initiatives to assist exporting firms in general including those engaged with environmental technology to overcome export related barriers (Kanda et al., 2013). Like the environmental technology sector itself, these governmental initiatives and the academic discourse around them is relatively new. Relevant discussions revolve around particular characteristics of environmental technology export; tailoring and/or generalization of governmental export

\footnotetext{
1 We use the term environmental technology in a broad sense: technologies whose development, market introduction, and use actually provide or are intended to provide an environmental performance better than their relevant alternatives from a life-cycle perspective. This broad definition is intended to capture export promotion initiatives across different countries acknowledging the different definitions, meanings, and scopes associated with the term "environmental technology". Examples can include services such as car sharing, products such as electric vehicles and systems such as biogas systems for transportation.
} 
promotion initiatives, and more importantly how to promote the export of environmental technologies within the framework of sustainability.

Accordingly, the related scientific discourse on governmental initiatives to promote the export of environmental technologies is still budding. For example, in the environmental technology diffusion literature (e.g. Montalvo and Kemp, 2008), export is identified as important for technology diffusion but is yet to receive further attention as to the different governmental initiatives available for technology providers and their potential relevance for environmental sustainability $^{2}$. On the other hand, the trade and policy literatures (e.g. Kumcu et al., 1995; Lederman et al., 2010) discuss export promotion in general, with no particular attention to technology characteristics and environmental sustainability. These opportunities identified in different bodies of literature culminate into a knowledge gap which needs to be addressed in search for different pathways to sustainability. To address this knowledge gap, the aim of this article is to analyse governmental initiatives to promote the export of environmental technologies and their potential relevance for environmental sustainability.

To support this aim, the central research questions addressed in this article are:

- What are the governmental export promotion initiatives available for environmental technology providers in different countries?

- What are the similarities and differences between governmental export promotion initiatives in different countries and how do these relate to environmental sustainability?

To provide a foundation for addressing the aim and research questions, the content of the article is structured as follows. In Section 2, we discuss theories of market failure and comparative public policy as theoretical lenses to analyse our empirical findings in addition to a review of some previous literature on environmental technology diffusion and export promotion. In Section 3 we describe the research method. Section 4 synthesizes the findings on governmental export promotion initiatives available for environmental technology providers. Using theories and previous studies presented in Section 2, we discuss our findings on governmental initiatives and propose potential policy implications in Section 5.

\section{Theoretical background}

In this section, we review some previous literature on environmental technology diffusion and export promotion to place this article in academic context. We also discuss theories of market failures in export as an economic rationale for governmental export promotion and also comparative public policy theories as a basis to explain policy choices in different countries regarding promoting the export of environmental technologies.

\footnotetext{
${ }^{2}$ Environmental sustainability specifically could be defined as conditions of balance, resilience, and interconnectedness that allow human society to satisfy its needs while neither exceeding the capacity of its supporting ecosystem to continue to regenerate the services necessary to meet those needs (Morelli, 2013).
} 


\subsection{Environmental technology diffusion}

Technology diffusion describes the aggregate of adoption decisions by a population of potential adopters over time (Montalvo, 2008). Many factors (stimuli, drivers, and barriers) influence diffusion and they are often complex if not impossible to model in their entirety (Kemp and Volpi, 2008). Previous research has analysed the diffusion of environmental technologies in various contexts and from different perspectives. For example, Kemp and Volpi (2008) analyse factors governing diffusion mechanism in general, del Rio González (2009) analyses factors influencing the adoption decision at the firm level, and Mejía-Dugand et al. (2012) analyse factors facilitating the dissemination of such technologies in cities. At the firm level, the adoption of environmental technologies is influenced by a variety of socioeconomic and institutional factors (del Rio González, 2009). Some factors are internal to the firm - e.g., top management commitment and absorptive capacity including technological and human resource competence to assimilate and use the adopted technology. Other factors are external - e.g., adoption pressure from policy regulations and non-governmental organisations and the firm's networks, competitors, and customers. In addition, the adoption decision relates to particular characteristics of environmental technologies such as their compatibility and alignment with existing systems, their often high investment costs, and their long-term payback time (del Rio González, 2009). In a synthesis of environmental technology diffusion literature, Montalvo and Kemp (2008) identify governmental promotion as an important research trajectory.

\section{$2.2 \quad$ Export promotion}

Previous research has approached export promotion ${ }^{3}$ from two general perspectives - the government and the firm. From the government's perspective, studies have focused on programme formulation mechanisms, structure, delivery channels, and programme effectiveness (e.g. Lederman et al., 2010; OECD, 1994; Rose, 2007). From the firm's perspective, studies have focused on awareness, participation, and perceived program effectiveness (e.g., Kanda et al., 2013; Kumcu et al., 1995). The export of environmental technologies is gaining interest among several governments because of potential markets in emerging economies and the global scale of recent environmental problems. In addition, domestic markets for some environmental technologies could be saturated quickly and even decline, particularly in countries with small domestic markets thus making exporting an attractive option. Although several factors influence the international flow of technologies, export promotion represents one of the principal opportunities for governments to influence the volumes and types of technologies exported from their countries (OECD, 1994).

\subsection{Governmental export promotion- the economic rationale and political dimensions}

The promotion of export by governments can be analysed from at least two complementary perspectives. These perspectives relate first to the economic rationale for governmental export promotion and second to the political dimensions of such export promotion initiatives. The economic rationale assists in explaining why governments intervene in markets to promote

\footnotetext{
3 In this article, we refer to export promotion as governmental initiatives that aim to enhance the export of environmental technologies.
} 
export while the political dimension provides a basis to discuss causal explanations for the similarities and differences between governmental initiatives available in different countries. Core arguments from these two complementary perspectives i.e. the economic rationale and political dimensions of export promotion are elaborated in this sub-section and then later used as theoretical basis to analyse empirical data on export promotion.

The economic rationale for government intervention through export promotion is grounded on the theories of asymmetric information and market failures such as externalities associated with export (Lederman et al., 2010). An externality represents an economically significant effect of an activity, the consequences of which are borne (at least in part) by a party or parties other than the party that controls the externality producing activity (Jaffe, 2005). Externalities can be labelled as negative when an individual or firm making a decision does not have to pay the full cost of the decision while a positive externality is a benefit that is enjoyed by an individual or firm as a result of an economic activity they have not directly paid for. In export, positive externalities exist regarding the collection of foreign market information related to consumer preferences, laws, regulations, business opportunities, etc. Private exporters often hesitate to undertake such market research by themselves as the cost involved can be significant and their competitors could benefit from their investments in such market research. A similar challenge of externalities is encountered by pace setters in export who make ground-breaking investments to open foreign markets, establish contacts, develop distribution channels, and engage in other costly measures that could benefit their rivals in export (Lederman et al., 2010). These constitute a market failure, a situation in which the market fails to arrange production and /or consumption in such a way that the allocation of resources is efficient (Borooah, 2003). Another source of market failure in export is information asymmetry among market players (Beltzér and Zetterqvist, 2008). In such situations, market players may be oblivious of or misjudge the risks and rewards associated with export activities and thus trade and export would occur at lower levels than optimal. The uncertainty introduced by political and economic risks associated with export has also been used to justify export credits and guarantees financed by the public sector (Lederman et al., 2010).

In tackling such market failures, government's concern is to design and implement strategies that correct such irregularities and create a level playing field for exporters (European Commission, 2007). A central hypothesis is that firms engaged in export, particularly small and medium sized firms often do not have the necessary resources to tackle such externalities and information asymmetries in export. And even when firms have such resources, the resources would be used restrictively knowing the potential spillover of benefits to their competitors. Thus it is often the role of governmental initiatives to provide support to such firms to tackle export related market failures. On the side of the governments, there are benefits to gain from promoting such firms in export, for example foreign exchange, employment opportunities and value addition, all of which contribute to national economic competitiveness. On the other hand, such market failures also provide room for private entrepreneurs such as consultants and banks who do export promotion for a fee. However, as this economic rationale provides a justification for governmental export promotion, it does not 
exhaust our questions regarding similarities and differences between governmental initiatives in various countries. A political dimension to export promotion is thus also discussed as a basis for such explanation.

Comparative public policy is defined by the trilogy of "ideas", "interests", and "institutions" (Blyth, 2009). Ideas relate to human agency, essentially suggesting that individual autonomous actions can have a significant effect on public policy making. However since, data collected and analysed in this article are not on the individual policy maker level - i.e. their autonomous ideas, this aspect of comparative policy will not be elaborated further.

The second aspect of comparative public policy relates to interests. There is no universallyaccepted definition of interests, however seminal works by Gourevitch (1986), considers interests as the materially derived preferences of social actors. In his regard, impulses from the economy alters the preferences of social actors based on their assets and resources, and these social actors in response act as brokers and attempt to form new coalitions of common interest. These coalitions then seek power in order to advance public policies to benefit themselves at the expense of competing coalitions. Indeed, the central hypothesis in the interest based explanation in political economy is that, to explain state's political choices, materially derived preferences, political brokerage and coalitional politics should be given particular attention. In addition to "interests", other concepts under the umbrella of comparative public policy offer to explain a state's policy choices by referring to institutions. One influential definition of institutions regards them as "formal rules, compliance procedures and standard operating practices that structure the relationship between individuals in various units of the polity and the economy" (Hall, 1986). In this view, the interests of social actors such as policy makers are mediated by their institutional contexts. In particular institutions serve as the context within which policy makers make their choice, provides stability for policy making and constraints individual behaviour. Thus institutions structure policy choices by social learning such that, radical policy options remain off the table (Blyth, 2009). Analysis of the influence of institutions on policy choices can take a historical, sociological and/or rational choice perspective (Dodds, 2012). The core argument of historical institutionalists is that decisions taken at the formation of an institution shape its trajectory in a path dependent way, constraining future policy options based on an inflation or deflation of financial and political costs, and the perceived feasibility of different policy options. The sociological approach stresses that, actors will do what appears "appropriate" rather than necessarily calculating carefully the likely impacts of their actions. While a rational choice perspective postulates an efficient creation and maintenance of institutions based on transaction costs (Dodds, 2012). In synthesis, "institutions" and "interests" would serve as theoretical basis in giving causal explanations for the similarities and differences between governmental initiatives for export promotion under section 5 .

\section{Method}

This study is motivated by knowledge gaps and questions relating to the promotion of environmental technology export. We chose to use qualitative exploratory research because such a strategy gives a greater understanding of a topic of study with room for unanticipated 
insights. Specifically, we reviewed existing empirical data on governmental initiatives to promote environmental technology export. The following sub-sections describe case selection, collection of empirical information, and the analysis of empirical data.

\subsection{Case selection and characteristics}

To explore the knowledge gap, we collected empirical information on governmental initiatives that aim to promote export of environmental technology from eight purposively selected countries. Germany, USA, and Japan were selected because they represent the top three exporters of environmental technology determined by number of patents and market surplus which to some extent gave an indication of the likelihood of finding relevant governmental export promotion initiatives. We selected Denmark, Sweden, Finland, and Norway because they represent the Scandinavian leaders in environmental technology and have relatively small domestic markets that would benefit from export activities. These two characteristics suggest that these countries would engage and have an interest in governmental initiatives to promote environmental technology export. Austria, an emerging country in the environmental technology sector, was selected because it has indicated on the national level the desire for strong and continued growth in the sector as is evident by a number of governmental initiatives being formulated to that effect (WWF, 2012). These eight countries (Germany, USA, Japan, Denmark, Sweden, Finland, Norway, and Austria) were selected to find governmental initiatives geared towards promoting environmental technology export. In addition, since export promotion initiatives are often unique in relation to the economic, cultural, legal, and political idiosyncrasies of each country (Leonidou et al., 2011), any similarities between governmental initiatives could be relevant for environmental technology export promotion and policy in general.

Table 1: overview of the environmental technology sector in the selected countries.

\section{$<<$ Position of Table 1 >>}

Table 1 presents some characteristics of the environmental technology sector in the studied countries. The most recent data have been compiled where available from the official statistics agency in each country and sometimes from the OECD statistics database. In some cases data were not available and thus we labelled the entry as "N/A". Information on the environmental technology sector for Japan is missing from the OECD statistics database and also inaccessible from the national statistics agency due to language barriers. Furthermore, it should be noted that the environmental technology sector is challenging to define and measure since it cuts across several industrial sectors and is defined differently in different counties. Thus we adopted a broad understanding of the term "environmental technology" - as technologies which actually provide or are intended to provide an environmental performance better than their relevant alternatives from a life-cycle perspective as presented in the introduction section.

\subsection{Collection of empirical information on governmental initiatives}

For each country, we collected information from official documentation of action plans for environmental technology development, market introduction, and diffusion, in addition to 
information from websites and reports of the official export promotion agencies (EXPAs) and export credit agencies (EXCAs). See Table 2 for coverage of data collection on governmental initiatives. The collected information included general export promotion initiatives, which can be accessed by all exporters, and specific initiatives targeted at environmental technology exporters. This explorative approach is appropriate for studying a relatively new phenomenon such as environmental technology export, and the multiple countries selected contribute to the reliability of the results as discussed by Yin (2008). To deal with the large volume of information available, we decided to focus on activities of the official export credit and export promotion agencies in each country as these agencies have an explicit mandate to promote export, although we acknowledge that the activities of other governmental agencies in each country could in one way or the other be argued to promote export. Recognising that governmental initiatives may have been initiated in the past, abandoned, and/or changed, we collected information covering a ten year period, from 2002 to 2012.

Table 2: Review coverage showing selected countries, official export (credit/promotion) agencies, and accessed reports.

$<<$ Position of Table 2>>

\subsection{Analysis of similarities and differences}

It should be reiterated that, a primary goal of this article is to synthesize governmental initiatives that aim to promote the export of environmental technology serving as a basis for further studies. This is because, there is no such systematic overview of governmental initiatives to the best of our knowledge in the technology diffusion literature. This study is thus based on governmental reports and information which has been critically analysed to draw conclusions in a qualitative manner. Using information from the selected countries, we identified and categorised governmental initiatives that aim to promote the export of environmental technologies. We then used theories of market failure and externalities to analyse each country's initiatives, highlighting and explaining similarities and differences using comparative public policy theories. These theories are used in two complementary ways. The theories of market failure highlight the classical economic explanation as to why governments intervene through export promotion while the comparative public policy theories offer useful insights to explain the different kinds of export promotion initiatives that exist in each country. Identifying governmental initiatives that target environmental technology exporters can be difficult because some countries have no dedicated initiatives specifically designed for environmental technology exporters, although they may have initiatives for exporters in general. Therefore, we have included these general initiatives because we consider them also relevant and accessible to environmental technology exporters as well.

Another challenge to highlighting similarities and differences is associated with the definition of environmental technology as there is no consistent definition of the concept across the countries studied. To ensure we identified all the governmental initiatives and empirical information relevant for the aims of this study, we adopted a broad understanding of the term 
"environmental technology" as presented in the introduction section. We critically read the empirical information before declaring it as relevant or not for the aims of this study. On the similarities and differences, export promotion initiatives are related to the idiosyncrasies of each country and thus our objective was to highlight similarities and differences which are relevant for environmental sustainability and discuss the political dimensions of such choices. Our goal was not to judge which country's initiatives were better, but to analyse which export promotion initiatives are potentially relevant for environmental sustainability from the selected countries. 


\section{Governmental initiatives}

Governmental initiatives to promote the export of environmental technology presented in this section are based on sources provided in Table 2 in section 3.2. After reviewing the various country initiatives, we synthesized the governmental initiatives into various categories and implementation options as shown in Figure 1 below. The synthesis is first of all provided to give the reader an overview before detailed elaboration of the initiatives and implementation options are presented.

\section{$<<$ Position of Figure 1 $>>$}

Figure 1: Governmental initiatives and implementation options for promoting environmental technology export

As can be seen in Figure 1 above, "governmental initiatives" depict in principle the different programs the selected governments use to promote export in general as well as environmental technology export in particular. The four categories of governmental initiatives are synthesised from the empirical material we scrutinized and also supported by previous literature on export promotion (see Leonidou et al., 2011). The implementation option "priority target markets" describes the different target markets each government has chosen to focus on. To provide some abstraction based on the various target markets, we adopt four categorisations used to describe a market's phases in environmental technology development - (i) early markets (ii) early infrastructure development markets (iii) regulatory enforcement markets (iv) resource productivity and market based instruments market by the Department for Environment, Food and Rural Affairs and the Department of Trade and Industry of the United Kingdom (DEFRA and DTI, 2002). We adopt this categorisation because it is broad enough to incorporate different kinds of markets and categorizations we found in the empirical data. The option "priority environmental technology" refers to environmental technologies that the selected country governments have chosen to prioritize in their export promotion efforts. The four options provided - (i) products (ii) services (iii) product service systems (iv) large technical systems are abstracted based on the characteristics of the priority environmental technology types detected in the empirical data. Firm stage in export refers to the firm's development in export ambitions with the options provided based on the empirics and structured according to the stage model to internationalization - (i) no regular export (ii) export via agents (iii) sales subsidiaries (iv) production (Johanson and Vahlne, 1977). Firm size is based on number of employees and turnover. These categorisations and implementation options are not mutually exclusive and exist in various combinations in each country. The governmental initiatives are elaborated in the following sub-section under the different governmental initiatives - financial aid, information, education and training, and trade and mobility-related programs.

\subsection{Financial aid-related programs}

Empirical information reviewed from all eight selected countries indicated the existence of a dedicated governmental agency responsible for export financing - "export credit agency". Each country's agency and official website is provided in Table 2. The existence of financial 
aid-related initiatives is supposed to cover the political and economic risk of buyer default during export and the activities of such agencies are targeted at mitigating such risk. The activities of these export credit agencies not only guarantee against buyer default but also offer credit guarantees and loans to facilitate export. Support from export credit agencies in the selected countries is available to exporters in general, including those exporting environmental technologies. In many cases, exporters seeking financial support will have to go through a screening process based mostly on the financial risks in the target market and buyer risk of default.

Despite the similar financial aid initiatives available for all exporters, including environmental technology exporters in the selected countries, some countries have initiatives specifically tailored for environmental technology exporters. For example, the export credit agency in Denmark, Eksport Kredit Fonden (EKF), provides environmental technology exporters financial support through a program called the "Cleantech guarantee", insuring exporters against buyer defaults based on particular characteristics of environmental technology as well as risks related to economic and political default. In addition, the "Cleantech guarantee" covers potential defaults in environmental technology export related to utility costs savings, failure to issue carbon credits, and financing energy service companies. The particular support offered to Danish environmental technology exporters goes beyond the export phase and into the use phase of the technology where potential environmental benefits might accrue.

\subsection{Information-related programs}

All the selected countries use other governmental agencies - "export promotion agencies" with an official mandate to promote export. The names and official websites of these agencies for the selected countries are provided in Table 2. The export promotion agencies mostly focus on other export promotion activities apart from export financing. Information-related programs that support exporters refer to market information provided to firms and potential customers about export opportunities, export regulations, sector characteristics, consumer preferences, laws, and regulations both in the home and target markets. For environmental technology exporters, governmental initiatives in some countries emphasise the provision of information on policy and legislation in the target market because of its influence in the adoption of particularly end-of-pipe environmental technologies. Information-related promotion programs are provided to firms using trade fairs, marketing campaigns, seminars, events for journalist, and exhibitions for exporters irrespective of technology type. Other information platforms for exporters include virtual networks and market places for information sharing and business matchmaking as well as through industry publications. The information provision activities of the export promotion agencies are facilitated by information often gathered by embassies and consulates in the target market. Such information is provided to exporters for a consultation fee or for free depending on the content and working package of the promotion agency.

\subsection{Education and training-related programs}

Doing business in foreign markets is often a much more complicated activity for firms than doing business in domestic markets (Fillis, 2002). In this regard, several of the selected countries have education and training activities for firms interested in exporting and for those 
firms already exporting. This support covers basic export management activities such as documentation, logistics management, foreign language training, and export sales. These education and training activities are open to all exporters, including environmental technology exporters. The training and education support activity is implemented through workshops, seminars, conferences on export planning, foreign market identification, and export logistics. Education and training can also focus on the use of the environmental technology itself. For example, many countries offer training for public officials, company executives, and engineers from target markets with a focus on using environmental technologies to solve specific problems to increase their familiarity with each other and potentially generate business interests and export activities in the long term.

\subsection{Trade mobility-related programs}

Another category of support activities closely related to information flow is trade mobilityrelated programs. These support programs encompass information flow between the home and target markets, and governments in the selected countries provide support to exporters to participate in such information flow activities. Trade mobility programs help firms rent and decorate spaces at trade fairs and exhibitions. The support can also cover financial aspects for exporters to invite potential foreign customers to the home market or organise business delegations to visit the target market to exploit marketing efforts. Other activities also include financial support to enable exporters to establish initial contacts with customers and prepare trade visits, including logistics support from trade offices in the target market.

As depicted in Figure 1, governmental initiatives to promote the export of environmental technologies are in principle similar to initiatives for exporters in general. However, these governmental initiatives are applied across different implementation options - priority target markets, technologies, firm stage in export and firm size. These different implementation options are described next.

\subsection{Implementation options of governmental initiatives}

Initiatives to promote the export of environmental technologies from some of the selected countries are focused on priority targets relating to specific markets, environmental technology type, firm size, and firm involvement in export. Many of the countries had priority target markets and environmental technology types for which they focus financing, information provision, and trade mobility-related activities, including demonstration projects and collaborations. In Austria, for example, environmental technology export promotion activities focus on Central and Eastern Europe, Asia, and Africa as priority markets with priority technologies, including wastewater treatment, solid waste treatment, recycling, and water supply. In Denmark, the focus is on exporting to the USA, Brazil, Russia, India, and China energy efficiency technologies, wind energy, biomass processing technology, and waste management. In Finland, the priority technology types are identified as renewable energy, recycling of materials, resource saving processes, energy saving technologies, and water treatment but with no specific target markets. In Norway, support is for investments and capacity building related to hydropower development, solar energy technologies, and other renewable energy technologies with priority markets in south-eastern Europe and sub-Saharan Africa. In Sweden, the focus is on sustainable building, transport, energy, water management, 
and waste targeted at Baltic countries and Russia, Western Europe, North America, Brazil, India, and China (details of these prioritisations are available in references provided in Table 2). Other prioritisation in the selected countries dominantly focused on small- and mediumsized companies. This could be because such companies dominate the environmental technology sector in many countries, face particular challenges in export such as financial, time and human recourse constraints, and demonstrate the potential for export growth and revenues. When it comes to the stage in export, implementation of governmental initiatives varied from those targeted at already exporting companies to those intended to encouraging non-exporters to begin exporting. The categories of governmental export initiatives and implementation options discussed above, together with the theories of market failure and technology diffusion serve as material for the concluding discussions.

Based on the country examples provided above, Table 3 below synthesizes promotion initiatives from the various countries. This synthesis is to facilitate the identification of different patterns regarding similarities and differences between governmental initiatives from various countries.

Table 3: Patterns of governmental initiatives to promote environmental technology export $<<$ Position of Table 3>>

The above synthesis of the governmental initiatives from various countries to promote the export of environmental technologies makes three things clear. First, the governmental initiatives to promote the export of environmental technology are in principle similar between the studied countries i.e. (i) financial aid-related programs, (ii) information related programs (iii) education and training related programs (iv) trade and mobility related programs. Second, the governmental initiatives are largely targeted at small and medium-sized regular exporters as well as non-exporters. Third, the implementation options for these governmental initiatives are different between selected countries in relation to the target markets and the environmental technology types as shown in Table 3 above. These similarities and differences are discussed further in the next section using theories from market failure and comparative public policy presented in Section 2.

\section{Concluding discussions}

We will discuss the previously presented findings in three steps. First, we discuss similarities between governmental initiatives from various countries and their relevance for environmental sustainability. Second, we will elaborate on differences between governmental initiatives including their potential relevance for environmental sustainability and in the third and final step discuss potential policy implications from the study. Conclusions from these discussions serve as our basis for identifying further research trajectories. 


\subsection{Similarities between governmental initiatives}

As shown in Table 3, two major similarities between governmental initiatives is the focus on promoting small-and medium-sized companies (SMEs) and, promoting both exporting firms and non-exporting firms.

\section{Focus on promoting SMEs}

A causal explanation for promoting SMEs in export relates both to the interests of policy actors and the challenges experienced by SMEs in export. A central theme towards economic competitiveness is developing a group of diverse and competitive small and medium sized enterprises which are crucial in a country's economic growth and overall production network. Furthermore, in most of the studied countries, SMEs comprise over $98 \%$ of the environmental technology sector and thus need to be promoted in export if the environmental technology sector is to contribute to economic competitiveness through the creation of jobs and contribution to gross domestic product. On the other hand, SMEs encounter challenges such as lack of experienced personnel, financial constraints, and limited knowledge of foreign markets, conditions that are often related to their size. Several governments, recognising the challenges and opportunities SMEs represent, have decided to target them for export promotion initiatives. Despite this, SMEs often complain that it is difficult to access governmental export promotion initiatives due to their resource constraints, the generic and often bureaucratic nature of the initiatives, including the large number of promoters involved (Kanda et al., 2013). More so, SMEs are often the focus of export promotion initiatives in general and thus promotion initiatives are often bundled together for all kinds of SMEs without any particular attention to their respective technologies, an approach often aimed at efficiently using public resource allocated for export promotion.

\section{Focus on promoting exporters and non-exporters}

The selected countries have a similar policy choice of promoting both exporters and nonexporters in export. This policy choice links to the interest of political actors for using export as an integral part of economic development. In addition to promotion export among already exporting firms, non-exporters represent an interesting target for governmental export promotion initiatives since they represent potential future exporters. Considering nonexporters would allow governments to anticipate and tackle their barriers to export and thus potentially spark their interest in exporting activities. This goes to underline the fact that, the success of export promotion initiatives also depends on the spectrum of companies engaged in export and thus initiatives should focus on encouraging exporters and non-exporters as well. In other words, the larger the number of companies engaged in export, the higher the probability of realising export growth and economic development which is of interest to political actors engaged in export promotion (Leonidou et al., 2011). 


\subsection{Differences between governmental initiatives}

As depicted in Figure 1, governmental export promotion initiatives available for environmental technology providers in principle could be categorised according to (i) financial aid, (ii) information provision, (iii) education and training, and (iv) trade mobilityrelated programs. These governmental initiatives are implemented across different target markets; environmental technology types in the studied countries (see Table 3). Within the framework of environmental sustainability, relevant differences exist between governmental initiatives in at least three aspects: the type of financial aid available for environmental technology exporters in some countries, the choice of priority target markets, and environmental technologies to promote.

\section{Financial-aid programs}

Financial aid in the form of export credits and guarantees is provided by dedicated export credit agencies to exporters in general in the studied countries. Financial support according to market failure theories is motivated by the political and economic risks including externalities experienced in export (Lederman et al., 2010). Nonetheless, in Denmark, there is tailored financial aid for environmental technology exporters, a service that is managed under the "Cleantech guarantee" program. This tailored financial service incorporates particular characteristics of environmental technologies such as environmental benefits and a life cycle perspective. Thus, there is financial support available for guarantees that address utility cost savings, guarantees for financing energy service companies, and guarantees against failure to issue carbon credits. This particular financial support offered in Denmark goes beyond support for the initial sale of an environmental technology; the support continues into the use phase of the technology and the associated risks of buyer default on environmental benefits.

This tailored financial scheme can be linked to the historical position of Denmark as a global leader in developing and exporting certain environmental technology types e.g. wind turbines. In addition, Denmark ranks as the global leader in providing drivers specific for environmental technology innovation such as the public R\&D share for environmental technology relative to the size of the national economy, a high number of supportive environmental technology clusters and government policies (WWF, 2014). This historical development has made the environmental technology sector an integral part of the Danish economy (The Danish Government, 2010) which means that firms in the sector are given particular attention. Linking back to comparative public policy theory, the interest of policy actors for economic competitiveness is mediated by the institutional context which produces a path dependency effect emerging from the integral position the environmental technology sector hold's in the Danish economy. This form of financial support is particularly relevant for environmental sustainability because of the environmental benefit and life cycle dimension. For example, business models such as product service system offerings, which go beyond selling products and into the delivery of functions, have shown higher environmental improvements in real cases (Lindahl et al., 2014) and could benefit from such kinds of financial support along the product life cycle. Nonetheless, financial aid in general is appreciated largely by environmental technology exporters (see Kanda et al., 2013). 
On the other hand, it is rather intriguing that countries with some similar profiles as Denmark, (e.g. export dependent, global leaders in the development of environmental technologies) like Sweden and Norway have chosen to provide financial-aid programs for exporters in general without any tailoring towards the environmental technology sector. This observation could be linked to export promotion policy discourses in Sweden and Norway which have largely been directed at creating framework conditions which nourishes export in general rather than export of particular technologies. Nonetheless, the technology policy literature advocates for a combination of initiatives which create both general framework conditions as well as tailored initiatives which address barriers particular to environmental technology providers (CarrilloHermosilla et al., 2009).

\section{Priority target markets}

The choice of priority target markets could be influenced by different reasons, including each country's environmental technology competence, the market demand for environmental technologies, psychological proximity (similar language, culture, political systems, education, and industrial development), existing environmental challenges, and existing trade relations. As environmental sustainability criteria differ based on spatial, temporal, and cultural embeddedness (Boons et al., 2013), characteristics of the target markets (e.g., industrial development, environmental regulations, and final consumers/industrial clients) can influence environmental improvements stimulated by technology exports. For example, emerging markets such as many markets in parts of Africa and south-east Asia (e.g., Vietnam) have underdeveloped environmental markets, and environmental investments are limited (DEFRA and DTI, 2002). In such markets, investments in environmental technology focus on end-ofpipe solutions such as waste water treatment and solid waste management. Other target markets such as Western Europe, North America, and Japan represent more mature environmental markets where fiscal and economic incentives for environmental improvement and resource effectiveness already exist. These markets are characterised by the development and use of integrated cleaner production processes and development of eco-efficient activities (e.g., recycling, renewable energy, and corporate environmental sustainability) beyond basic compliance (DEFRA and DTI, 2002).

As shown in Table 3, the countries prioritise different target markets in the spectrum between emerging to matured environmental markets. In explaining these political choices, the comparative public policy theory point to a path dependency based on countries' technology competence as mediating the interest of social actors in choosing certain target markets. For example, in Austria, there is an ambition to develop environmental technology leadership in Europe (The Austrian Government, 2005). This ambition started with a task to develop the national environmental technology competence in certain technologies as a basis for export strategies. Consequently, such technologies (wastewater treatment, waste treatment, recycling, and water supply) see Table 3 are potentially suited for certain markets (Central and Eastern Europe, Asia, Africa) chosen as priority in Austria. Nonetheless a choice between different environmental markets presents different challenges. For example while the potential need for certain types of environmental technologies could be deemed as existent in emerging markets, framework conditions such as regulations, customer awareness, political and economic risks 
may not be favourable. On matured markets with often market based incentives for the adoption of environmental technologies, framework conditions may be favourable but with fierce competition from various local and international technology providers.

\section{Priority technology types}

Differences also exist between governmental initiatives with respect to the type of environmental technology they prioritise to promote (see Table 3). Some countries e.g. Austria focus on promoting technologies for "end-of-pipe" solutions (e.g., waste and wastewater treatment), whereas other countries e.g. Denmark focus on technologies for "front-of-pipe" solutions (e.g., material and energy-efficiency technologies and renewable technologies). The term "end-of-pipe" refers to technologies for reactive environmental protection such as the installation of filters, waste water treatment which tend to contain emissions, pollutants which have already occurred to render then controllable. On the other hand, "front-of-pipe" refers to technologies to reduce resource use and prevent pollution in the first place. The motivation for these policy choices can be inferred from the path dependency created by the institutional context (national competence over the full value chain from technology providers, system builders, operators to end users) as argued in comparative policy theory. And as supported by the empirical data, Denmark focuses on wind turbines while; Sweden prioritises sustainable transportation, technologies which these two countries are renowned global leaders in development and implementation (WWF, 2014). For environmental sustainability, some previous literature discusses how different environmental technology types have different determinants for their adoption and environmental improvements (e.g. del Rio González, 2009). Certain features of front-of-pipe environmental technologies - e.g., their complexity, their disturbance of existing production systems, and their often high initial investment costs - often make it difficult for firms to invest in such technologies, whereas end-of-pipe environmental technologies, as they cause little disturbance to existing systems, are more likely to be adopted under regulatory pressure (del Rio González, 2009). However, it is a combination of both end-of-pipe and front-of-pipe technologies that can deliver relevant improvements needed for environmental sustainability (OECD, 2009).

\subsection{Implications for policy}

The discussions in this article have potential implications for environmental technology policy in general and environmental technology export promotion policy in particular. Environmental technology policy tackles problems associated with the reluctance of the private sector to engage in activities with diffused benefits in relation to the use of the natural environment, example environmental pollution. Though the strategies to tackle such environmental externalities differ across countries, a key hypothesis in the environmental technology policy literature is the need to provide incentives for technology providers in the process of developing and implementing new technologies (Schubert and Sedlacek, 2005). The contributions presented in this article point to the provision of incentives for technology providers in international markets, a discussion which is yet to be addressed in the environmental technology policy discourse. Essentially we raise awareness that, the 
formulation of environmental technology policy will increasingly need to look beyond national borders into international markets particularly with the issue of sustainability remaining a global agenda.

On governmental initiatives to promote environmental technology export, a policy question relates to how generally or sector-specific promotion initiatives should be formulated. Though the environmental technology policy literature advocates for a mix between general and sector specific initiatives in supporting the sector (del Río et al., 2010), the discussions in this article reveal that the selected countries largely promote environmental technology export with framework initiatives available for exporters in general with the exception of sector-specific action plans formulated in the last decade in some countries (see Table 2). The related academic literature, (eg. Kumcu et al.,1995 and Lederman et al.,2010) have bundled export promotion without attention to characteristics of particular technologies. Though Kanda et al.,(2013) highlights the dissatisfaction from environmental technology providers with the generic nature of promotion initiatives, the approach could relate to their market complementarity nature of public policy and thus should not be expected to fulfil very specific sector needs. In addition, financial resource constraints on the side of government agencies make a generic approach potentially resource efficient. Nonetheless, environmental technologies providers experience both general as well as sector specific barriers in export (Kairento and Nygårds, 2014) which points to a mix between general as well as sectorspecific promotion initiatives as particularly interesting for environmental sustainability goals.

Another important policy discussion is the implementation of export promotion initiatives. The usefulness of export promotion relies not only on formulated initiatives but also how they are implemented (Lederman et al., 2010). As key recipients of export promotion initiatives are SMEs, the implementation of such initiatives should consider their particular characteristics. This is particularly important for the environmental technology sector since it has received increased attention in recent years with a proliferation of governmental actors and initiatives working to strengthen the sector in many countries. Thus collaboration and learning between different actors both public and private influences the effectiveness of policy initiatives particularly in the environmental technology sector (Ćetković, 2015). Finally, it should be mentioned that the conclusions drawn from these studies are based on selected cases and thus opportunities for generalization should be approached with caution as with any explorative research. Primarily, the methodological approach sheds insights into the phenomenon of environmental technology export promotion rather than to produce statistically generalizable results. Nonetheless we understand that export promotion initiatives can be idiosyncratic to each country; we expect some level of similarities between the studied initiatives and other countries outside our scope. Furthermore most of the selected countries fall within the European Union and policy initiatives formulated at such higher level e.g. the environmental technology action plan, ETAP (Calleja and Delgado, 2008) are expected to influence national level policy formulation including mimicking between countries, however as indicated in our conclusions, the implementation of such initiatives continues to differ on the local level in the studied countries. 


\subsection{Further research}

This article analyses various governmental initiatives aimed at promoting the export of environmental technologies and their potential relevance for environmental sustainability. A further step could be to evaluate the effectiveness of such export promotion initiatives in realizing export particularly at the firm level. With respect to the governmental initiatives themselves, particularly interesting questions relate to how to formulate and implement export promotion initiatives under the framework of sustainability, and how to integrate international technology diffusion in environmental technology policy formulation. Theoretical insights could be opened up relating to the analysis of the market failure rationale and the systems failure rationale as the underlining justification for governmental interventions to promote the export of environmental technology.

\section{References}

Beltzér, C., Zetterqvist, M., 2008. An Evaluation of Swedish Export Promotion., Institute of International Economics. Stockholm School of Economics.

Blyth, M., 2009. An Approach to Comparative Analysis or a Subfield Within a Subfield? Political Economy. Comparative Politics: Rationality, Culture, and Structure, 193.

Boons, F., Montalvo, C., Quist, J., Wagner, M., 2013. Sustainable innovation, business models and economic performance: an overview. Journal of Cleaner Production 45, 18.

Borooah, V.K., 2003. Market Failure An Economic Analysis of its Causes and Consequences. Ulster: Ulster University Press.

Calleja, I., Delgado, L., 2008. European environmental technologies action plan (ETAP). Journal of Cleaner Production 16, S181-S183.

Carrillo-Hermosilla, J., del Río González, P., Könnöla, T., 2009. Eco-innovation: when sustainability and competitiveness shake hands. Palgrave Macmillan Hampshire.

Ćetković, S., 2015. Policy Capacity for Promoting Green Sectors Reconsidered: Lessons from the Renewable Electricity and Organic Farming Sectors in Serbia. Journal of Environmental Policy \& Planning 17, 65-83.

DEFRA, DTI, 2002. Global Environmental Markets and the UK Environmental Industry: Opportuinities to 2010, in: Department for Environment, F.a.R.A., Industry, D.f.T.a. (Eds.).

del Rio González, P., 2009. The empirical analysis of the determinants of technologicall change: A research agenda. Journal of ecological economics, 861-878.

del Río, P., Carrillo-Hermosilla, J., Könnölä, T., 2010. Policy Strategies to promote ecoinnovation: An Integrated Framework. Journal of Industrial Ecology 14, 541-557.

Dodds, A., 2012. Comparative public policy. Palgrave Macmillan.

European Commission, 2007. Supporting the internationalisation of SMEs - Final report of the expert group., p. 38.

Fillis, I., 2002. Barriers to internationalisation-An investigation of the craft microenterprise. European Journal of Marketing, 912-927.

Finco, A., Nijkamp, P., 2001. Pathways to urban sustainability. Journal of Environmental Policy and Planning 3, 289-302.

Gourevitch, P., 1986. Politics in hard times: comparative responses to international economic crises. Cornell University Press.

Hall, P.A., 1986. Governing the economy: The politics of state intervention in Britain and France. 
Jaffe, A.B., Newell, R.G., Stavins, R.N., 2005. A tale of two market failures: Technology and environmental policy. Ecological Economics 54, 164-174.

Johanson, J., Vahlne, J.-E., 1977. The internationalization process of the firm-a model of knowledge development and increasing foreign market commitments. Journal of international business studies, 23-32.

Kairento, K., Nygårds, M., 2014. Export of municipal environmental technology knowledge : An analysis of previous activities and incentives $\langle\mathrm{em}\rangle\langle/ \mathrm{em}\rangle$.

Kanda, W., Mejía-Dugand, S., Hjelm, O., 2013. Governmental export promotion initiatives: awareness, participation, and perceived effectiveness among Swedish environmental technology firms. Journal of Cleaner Production.

Kemp, R., Volpi, M., 2008. The diffusion of clean technologies: a review with suggestions for future diffusion analysis. Journal of Cleaner Production 16, S14-S21.

Kumcu, E., Harcar, T., Kumcu, M.E., 1995. Managerial perceptions of the adequacy of export incentive programs: Implications for export-led economic development policy. Journal of Business Research 32, 163-174.

Lederman, D., Olarreaga, M., Payton, L., 2010. Export promotion agencies: Do they work? Journal of Development Economics 91, 257-265.

Leonidou, L.C., Palihawadana, D., Theodosiou, M., 2011. National export-promotion programs as drivers of organizational resources and capabilities: effects on strategy, competitive advantage, and performance. Journal of International Marketing 19, 1-29.

Lindahl, M., Sundin, E., Sakao, T., 2014. Environmental and economic benefits of Integrated Product Service Offerings quantified with real business cases. Journal of Cleaner Production 64, 288-296.

Montalvo, C., Kemp, R., 2008. Cleaner technology diffusion: case studies, modeling and policy. Journal of Cleaner Production 16, S1-S6.

Morelli, J., 2013. Environmental sustainability: A definition for environmental professionals. Journal of Environmental Sustainability 1,2.

OECD, 1994. Export promotion and environmental technologies, Paris, p. 26.

OECD, 2009. Eco-Innovation in Industry:Enabling green growth. OECD publishing, France.

Rennings, K., 2000. Redefining innovation-eco-innovation research and the contribution from ecological economics. Ecological Economics 32, 319-332.

Rennings, K., 2014. Introduction: Global diffusion of environmental innovations. Environmental Innovation and Societal Transitions 10, 1-3.

Rose, A.K., 2007. The foreign service and foreign trade: embassies as export promotion. The World Economy 30, 22-38.

Schubert, U., Sedlacek, S., 2005. The structure of environmental policy and environmentorientated technology policy signals for environment-orientated innovation. Journal of Environmental Policy and Planning 7, 317-339.

Suzuki, M., 2014. Identifying roles of international institutions in clean energy technology innovation and diffusion in the developing countries: matching barriers with roles of the institutions. Journal of Cleaner Production.

WWF, 2012. Coming clean: The Global Cleantech Innovation Index 2012. Cleantech group LLC; WWF

Yin, R.K., 2008. Case study research: Design and methods. SAGE Publications, Incorporated. 


\section{Government reports}

Federal Ministry for the Environment, Nature Conservation and Nuclear Safety, 2007. Export initiative: Recycling and efficient technologies. http://www.bmu.de/english/waste_management/doc/print/41950.php [Last accessed December 12, 2012]

Federal Ministry of Economics and Technology, 2002. Energy efficiency export initiative - a service to promote energy efficiency "made in Germany'. http://www.bmwi.de/English/Navigation/Energy-policy/energy-efficiency-exportinitiative.html [Last accessed December 12, 2012]

Sitra, the Finnish Innovation Fund, 2007. Cleantech Finland- improving the environment through business: Finland's national action plan to develop environmental business. http://solved.fi/sites/default/files/Cleantech\%20Finland\%20-

\%20improving\%20the\%20environment\%20through\%20business.pdf [Last accessed December 12, 2012]

Swentec. 2008. Handlingsplan för svensk miljöteknik [Action plan for Swedish cleantech]. http://www.lansstyrelsen.se/vasterbotten/SiteCollectionDocuments/Sv/miljo-och-

klimat/klimatochenergi/energiomstallning_Handlingsplan\%20f\%C3\%B6r\%20svensk\%20miljoteknik.pdf [Last accessed June 25, 2012].

Swentec, 2008. Swedish strategies and initiatives for promotion of environmental technologyA national roadmap for the implementation of the EU Action Plan for Environmental Technology, ETAP. http://www.eeconnections.net/pdf_files/swentec/Swedish\%20strategies\%20and\%20initiatives \%20for\%20promotion\%20of\%20environmental\%20technology\%20$\% 20$ A $\% 20$ National\%20Roadmap\%20for\%20the\%20implementation\%20of\%20ETAP.pdf [Last accessed December 12, 2012]

The Austrian Government, 2005. MUT Master Plan Environmental Technology-The future of Austrian Environmental Technology. http://www.google.se/url? sa=t\&rct=j\&q=\&esrc=s\&source=web\&cd=1\&ved=0CCsQFjAA\&u $\mathrm{rl}=\mathrm{http} \% 3 \mathrm{~A} \% 2 \mathrm{~F} \% 2 \mathrm{Fwww}$. lebensministerium.at $\% 2 \mathrm{Fdms} \% 2 \mathrm{Flmat} \% 2 \mathrm{Fumwelt} \% 2 \mathrm{Fbetr}-$ umweltschutz\%2Fumwelttechnologien\%2FUmwelttechnolgie\%2FBroschure_20MUT_20171 008_20eng_20endf-

\%2FBroschure_20MUT_20171008_20eng_20endf..pdf\&ei=5QHJUM_JDsfm4QSatICIBw\& usg=AFQjCNEhlqUYOBDE_CmyJIUlKohjBVEYgQ\&bvm=bv.1355272958,d.bGE [Last accessed December 12, 2012]

The Danish Government, 2006. Promoting eco-efficient technology-The roadmap to a better Environment. Available online at [Last accessed December 12, 2012] 
The Danish Government, 2007. Danish solutions to global environmental challenges: The government's action plan for promoting eco-efficient technology. http://ec.europa.eu/environment/ecoap/pdfs/roadmaps/denmark_en.pdf [Last accessed December 12, 2012]

The Danish Government, 2010. Environmental technology for improvement of the environment and growth: Action plan to promote eco-efficient technology 2010-2011. http://www.ecoinnovation.dk/NR/rdonlyres/BBD1582D-DF55-4799-94B2-

FBE4BDBB8053/0/Miljoeteknologi_plan_2010_engelsk.pdf [Last accessed December 12, 2012]

The Swedish Government. 2011. Strategi för utveckling och export av miljöteknik 2011-2014 [Strategy for development and export of environmental technology 2011-2014]. Available online at www.regeringen.se/sb/d/14218/a/174071 [Accessed May 27, 2012].The Trade Promotion Coordinating Committee, 2010. Renewable energy and energy efficiency export promotion initiative. Available online at [Last accessed December 12, 2012]

U.S. Department of Commerce and US-AEP, 2002. Korea environmental technologies export market plan. http://pdf.usaid.gov/pdf_docs/PNACQ720.pdf [Last accessed December 12, 2012]

U.S. Department of Commerce, 2003. United Kingdom environmental technologies export market Plan. http://www.ita.doc.gov/media/Publications/pdf/ukemp_112003.pdf [Last accessed December 12, 2012] 
Table 1: overview of the environmental technology sector in the selected countries.

\begin{tabular}{|c|c|c|c|c|c|}
\hline & Establishments & Employees & Turnover & Exports & Comments/Data source \\
\hline Austria & N/A & 185,122 & EUR 36.3 million & N/A & $\begin{array}{l}\text { All data from } 2013 \\
\text { http://www.statistik.at/web_en/statistics/EnergyEnvironmentInnovationMobili } \\
\text { ty/energy environment/environment/eco industries environmentally goods } \\
\underline{\text { and_services/index.html }}\end{array}$ \\
\hline Denmark & N/A & 57,953 & 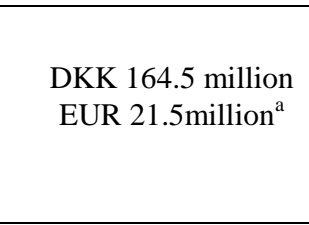 & $\begin{array}{l}\text { DKK } 65,4 \text { million } \\
\text { EUR } 8.5 \text { million }^{\mathrm{a}}\end{array}$ & $\begin{array}{l}\text { All data from } 2013 \\
\text { http://www.dst.dk/en/Statistik/emner/miljoe/miljoeoekonomisk-regnskab } \\
\underline{\text { http://www.statbank.dk/statbank5a/selectvarval/define.asp?PLanguage }=1 \& \text { su }} \\
\text { bword=tabsel\&MainTable=GRON1\&PXSId=184723\&tablestyle=\&ST=SD\& } \\
\frac{\text { buttons }=0}{{ }^{\mathrm{a}} \text { 1DKK }=0.13 \text { EUR }(2013)}\end{array}$ \\
\hline Finland & N/A & $88,569(2013)$ & $\begin{array}{c}\text { EUR 24,000 million } \\
\text { (2013) }\end{array}$ & $\begin{array}{c}\text { EUR 5,115 million } \\
\text { (2011) }\end{array}$ & $\begin{array}{l}\text { http://www.tilastokeskus.fi/tup/ymparistotilinpidon- } \\
\text { teemasivut/tuotteet_en.html } \\
\underline{\text { http://pxnet2.stat.fi/PXWeb/pxweb/en/StatFin/StatFin_ymp_ylt/010_ylt_tau }} \\
\text { _110.px }\end{array}$ \\
\hline Germany & 6,448 & 218,142 & EUR 52,888 million & EUR 24,183 million & $\begin{array}{l}\text { All data from } 2012 \\
\text { https://www.destatis.de/EN/FactsFigures/NationalEconomyEnvironment/Envi } \\
\underline{\text { ronment/EnvironmentalSurveys/EnvironmentalEconomics/Tables/TablesGoo }} \\
\underline{\text { dsServices.html }}\end{array}$ \\
\hline Norway & 1,786 & 38,000 & N/A & $\begin{array}{l}\text { NOK } 21.8 \text { billion } \\
\text { EUR } 283 \text { million }^{\mathrm{b}}\end{array}$ & $\begin{array}{l}\text { All data from } 2011 \\
\text { www.intpow.no/?id=1759\&download }=1 \\
{ }^{\mathrm{b}} 1 \mathrm{NOK}=0.13 \text { EUR }(2011)\end{array}$ \\
\hline Sweden & 16,434 & 71,980 & $\begin{array}{l}\text { SEK } 222.4 \text { million }^{\text {EUR } 26.7 \text { million }^{c}}\end{array}$ & 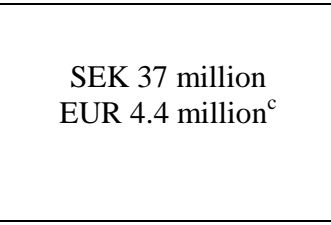 & $\begin{array}{l}\text { All data from } 2013 \\
\text { http://www.scb.se/en_/Finding-statistics/Statistics-by-subject- } \\
\text { area/Environment/Environmental-accounts-and-sustainable- } \\
\text { development/System-of-Environmental-and-Economic-Accounts/Aktuell- } \\
\text { Pong/38171/Environmental-sector/206293/ } \\
{ }^{\mathrm{c}} 1 \mathrm{SEK}=0.12 \text { EUR (2013) }\end{array}$ \\
\hline USA & $\begin{array}{c}119,000 \\
(2008)\end{array}$ & $3,401,279(2011)$ & N/A & 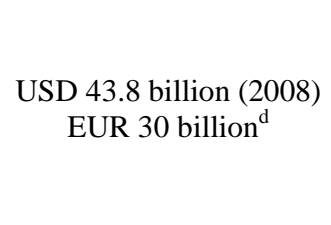 & $\begin{array}{l}\frac{\mathrm{http}: / / \text { www.bls.gov/ggs/ }}{\text { http://web.ita.doc.gov/ete/eteinfo.nsf/068f3801d047f26e85256883006ffa54/48 }} \\
\frac{78 \mathrm{~b} 7 \mathrm{e} 2 \mathrm{fc} 08 \mathrm{ac} 6 \mathrm{~d} 85256883006 \mathrm{c} 452 \mathrm{c} ? \text { OpenDocument }}{\text { http://environment.ita.doc.gov/ }} \\
{ }^{\mathrm{d}} \text { 1USD }=0.68 \text { EUR }\end{array}$ \\
\hline
\end{tabular}


Table 2: Review coverage showing selected countries, official export (credit/promotion) agencies, and accessed reports.

\begin{tabular}{|c|c|c|c|}
\hline & General export promotion initiatives & & Specific initiatives for environmental technology exporters \\
\hline Country & Export Credit Agency(ies) and websites & $\begin{array}{l}\text { Export Promotion Agency(ies) } \\
\text { and websites }\end{array}$ & Reports \\
\hline Austria & $\begin{array}{l}\text { Oesterreichische Kontrollbank AG (OeKB) } \\
\text { www.oekb.at }\end{array}$ & $\begin{array}{l}\text { Austrian Federal Economic } \\
\text { Chamber } \\
\text { portal.wko.at }\end{array}$ & $\begin{array}{l}\text { The Austrian Government, 2005. MUT Master Plan } \\
\text { Environmental Technology - The future of Austrian } \\
\text { Environmental Technology. }\end{array}$ \\
\hline Denmark & $\begin{array}{l}\text { Eksport Kredit Fonden (EKF) } \\
\text { www.ekf.dk }\end{array}$ & $\begin{array}{l}\text { The Danish Trade Council } \\
\text { um.dk/en/tradecouncil }\end{array}$ & $\begin{array}{l}\text { The Danish Government, 2006. Promoting eco-efficient } \\
\text { technology - The roadmap to a better Environment. } \\
\text { - The Danish Government, 2007. Danish solutions to global } \\
\text { environmental challenges: The government's action plan } \\
\text { for promoting eco-efficient technology. } \\
\text { - The Danish Government, 2010. Environmental technology } \\
\text { for improvement of the environment and growth: Action } \\
\text { plan to promote eco-efficient technology 2010-2011. }\end{array}$ \\
\hline Finland & $\begin{array}{l}\text { Finnvera Oyj } \\
\text { www.finvera.fi } \\
\text { Finnish Export Credit Ltd (FEC) } \\
\text { www.fec.fi }\end{array}$ & $\begin{array}{l}\text { Finpro } \\
\text { www.finpro.fi }\end{array}$ & $\begin{array}{l}\text { Sitra, the Finnish Innovation Fund, 2007. Cleantech Finland - } \\
\text { improving the environment through business: Finland's national } \\
\text { action plan to develop environmental business }\end{array}$ \\
\hline Germany & $\begin{array}{l}\text { AuslandsGeschäftsAbsicherung der } \\
\text { Bundesrepublik Deutschland } \\
\text { www.agaportal.de } \\
\text { Euler Hermes } \\
\text { www.hermes-kredit.com }\end{array}$ & $\begin{array}{l}\text { The Federal Office of } \\
\text { Economic and Export Control } \\
\text { (BAFA) } \\
\text { www.bafa.de } \\
\text { German trade and Invest } \\
\text { (GTAI) } \\
\text { www.gtai.de }\end{array}$ & $\begin{array}{l}\text { - Federal Ministry of Economics and Technology, } 2002 . \\
\text { Energy efficiency export initiative - a service to promote } \\
\text { energy efficiency "made in Germany" } \\
\text { - Federal Ministry for the Environment, Nature Conservation } \\
\text { and Nuclear Safety, 2007. Export initiative: Recycling and } \\
\text { efficient technologies }\end{array}$ \\
\hline
\end{tabular}




\begin{tabular}{|c|c|c|c|}
\hline Japan & $\begin{array}{l}\text { Nippon Export and Investment Insurance } \\
\text { (NEXI) } \\
\text { nexi.go.jp } \\
\text { Japan Bank for International Cooperation } \\
\text { (JBIC) } \\
\text { Www.jbic.go.jp }\end{array}$ & $\begin{array}{l}\text { The Japan External Trade } \\
\text { Organisation (JETRO) } \\
\text { www.jetro.go.jp }\end{array}$ & \\
\hline Norway & $\begin{array}{l}\text { The Norwegian Guarantee Institute for } \\
\text { Export Credits (GIEK) } \\
\text { www.giek.no }\end{array}$ & $\begin{array}{l}\text { Innovation Norway } \\
\text { www.innovasjonnorge.no }\end{array}$ & \\
\hline Sweden & $\begin{array}{l}\text { Exportkreditnämnden (EKN) } \\
\text { www.ekn.se } \\
\text { AB Svensk Exportkredit (SEK) } \\
\text { www.sek.se }\end{array}$ & $\begin{array}{l}\text { Swedish Trade Council and } \\
\text { Invest Council } \\
\underline{\text { www.business-sweden.se }}\end{array}$ & $\begin{array}{l}\text { - Swentec, 2008. Swedish strategies and initiatives for } \\
\text { promotion of environmental technology - A national } \\
\text { roadmap for the implementation of the EU Action Plan for } \\
\text { Environmental Technology, ETAP. } \\
\text { - Swentec, 2008. Action plan for Swedish cleantech. } \\
\text { - The Swedish Government, 2011. Strategy for development } \\
\text { and export of environmental technology, 2011-2014. }\end{array}$ \\
\hline USA & $\begin{array}{l}\text { Export-Import Bank of the United States } \\
\text { (Ex-Im Bank) } \\
\text { www.exim.gov }\end{array}$ & $\begin{array}{l}\text { The US International Trade } \\
\text { Administration (ITA) } \\
\text { trade.gov }\end{array}$ & $\begin{array}{l}\text { The Trade Promotion Coordinating Committee, } 2010 . \\
\text { Renewable energy and energy efficiency export promotion } \\
\text { initiative. } \\
\text { - U.S. Department of Commerce and US-AEP, 2002. Korea } \\
\text { environmental technologies export market plan. } \\
\text { U.S. Department of Commerce, 2003. United Kingdom } \\
\text { environmental technologies export market Plan. }\end{array}$ \\
\hline
\end{tabular}


Table 3: Patterns of governmental initiatives to promote environmental technology export

\begin{tabular}{|c|c|c|c|c|c|c|c|c|}
\hline \multirow[b]{2}{*}{$\begin{array}{l}\text { Implementation } \\
\text { options }\end{array}$} & \multicolumn{8}{|c|}{$\begin{array}{l}\text { Governmental export promotion initiatives } \\
\text { 1. Financial aid-related programs } \\
\text { 2. Information-related programs } \\
\text { 3. Education and training-related programs } \\
\text { 4. Trade and mobility-related programs }\end{array}$} \\
\hline & Austria & Denmark & Finland & Germany & Japan & Norway & Sweden & USA \\
\hline $\begin{array}{l}\text { Priority target } \\
\text { markets }\end{array}$ & $\begin{array}{l}\text { Central and } \\
\text { Eastern } \\
\text { Europe } \\
\text { Asia } \\
\text { Africa }\end{array}$ & \begin{tabular}{|l} 
US \\
"BRIC", \\
countries \\
(i.e., \\
Brazil, \\
Russia, \\
India, \\
China)
\end{tabular} & $\begin{array}{l}\text { No explicit } \\
\text { target } \\
\text { markets }\end{array}$ & $\begin{array}{l}\text { No explicit } \\
\text { target } \\
\text { markets }\end{array}$ & $\begin{array}{l}\text { No } \\
\text { explicit } \\
\text { target }\end{array}$ & $\begin{array}{l}\text { South East } \\
\text { Europe } \\
\text { Sub-saharan } \\
\text { Africa }\end{array}$ & $\begin{array}{l}\text { Western Europe } \\
\text { North America } \\
\text { Brazil, India, and } \\
\text { China Baltic states } \\
\text { Russia }\end{array}$ & $\begin{array}{l}\text { South Korea } \\
\text { China } \\
\text { India } \\
\text { Japan } \\
\text { UK }\end{array}$ \\
\hline $\begin{array}{l}\text { Priority } \\
\text { environmental } \\
\text { technology }\end{array}$ & $\begin{array}{l}\text { Wastewater } \\
\text { treatment } \\
\text { Waste } \\
\text { treatment } \\
\text { Recycling } \\
\text { Water } \\
\text { supply }\end{array}$ & \begin{tabular}{|l} 
Energy \\
efficiency \\
Wind \\
energy \\
Biomass \\
and waste \\
Aquatic \\
environme \\
nt
\end{tabular} & $\begin{array}{l}\text { Renewable } \\
\text { energy } \\
\text { Recycling } \\
\text { of } \\
\text { materials } \\
\text { Resource } \\
\text { saving } \\
\text { processes } \\
\text { Energy } \\
\text { saving } \\
\text { technologi } \\
\text { es } \\
\text { Water } \\
\text { treatment } \\
\end{array}$ & \begin{tabular}{|l|} 
Renewable \\
energies \\
Recycling \\
$\&$ \\
efficiency \\
technologi \\
es \\
Energy \\
efficiency \\
Water \\
Raw \\
materials \\
Climate \\
protection \\
\end{tabular} & $\begin{array}{l}\text { No } \\
\text { explicit } \\
\text { target }\end{array}$ & $\begin{array}{l}\text { Renewable } \\
\text { energy } \\
\text { Hydropower } \\
\text { Solar energy }\end{array}$ & \begin{tabular}{|l|} 
Sustainable \\
building \\
Transport \\
Energy \\
Water \& Waste \\
management
\end{tabular} & $\begin{array}{l}\text { Renewable energy } \\
\text { and energy } \\
\text { efficiency }\end{array}$ \\
\hline $\begin{array}{l}\text { Firm stage in } \\
\text { export }\end{array}$ & \multicolumn{8}{|c|}{ Regular exporters and non-exporters } \\
\hline Firm size & \multicolumn{8}{|c|}{ Small and medium sized companies } \\
\hline
\end{tabular}

